\title{
STOMACH CONTENT ANALYSIS OF BROOK TROUT AND RAINBOW TROUT
}

DON J. WARNER, Wildlife/Recreation Student, Forest Technology School, Hinton, Alberta.

Through electrofishing of Hardisty Creek and Baseline Creek, it was noted that both brook trout (Salvelinus fontinalis) and rainbow trout (Salmno gairdneri) were present in each of the creeks. This project was to see if the food habits of these fish allow them to be compatable species in creeks or lakes and find out how much competition there is for food. Therefore an analysis was conducted on the stomach contents of rainbow trout and brook trout.

Fish samples were collected by the use of a Smith-Root Type V ElectroFisher during the first two weeks of October, 1978. A modified volumetric method was used for the analysis of the stomach contents. ${ }^{1}$ Identification of the stomach contents was done as expressed in Needham. ${ }^{2}$

Nineteen fish were analyzed from each creek. Table 1 shows that the volume of stomach contents analyzed for brook trout is relatively equal to that analyzed for rainbow trout. Direct analysis of the stomach contents showed a difference in the diets of the two species (Figure 1).

Rainbow trout have less variation in their diet, where plecoptera and fish are of little importance, whereas in brook trout, plecoptera and fish are important to the diet with the rest of it being quite varied (Figure 1). The high percentage of unidentified
GROOK TROUT
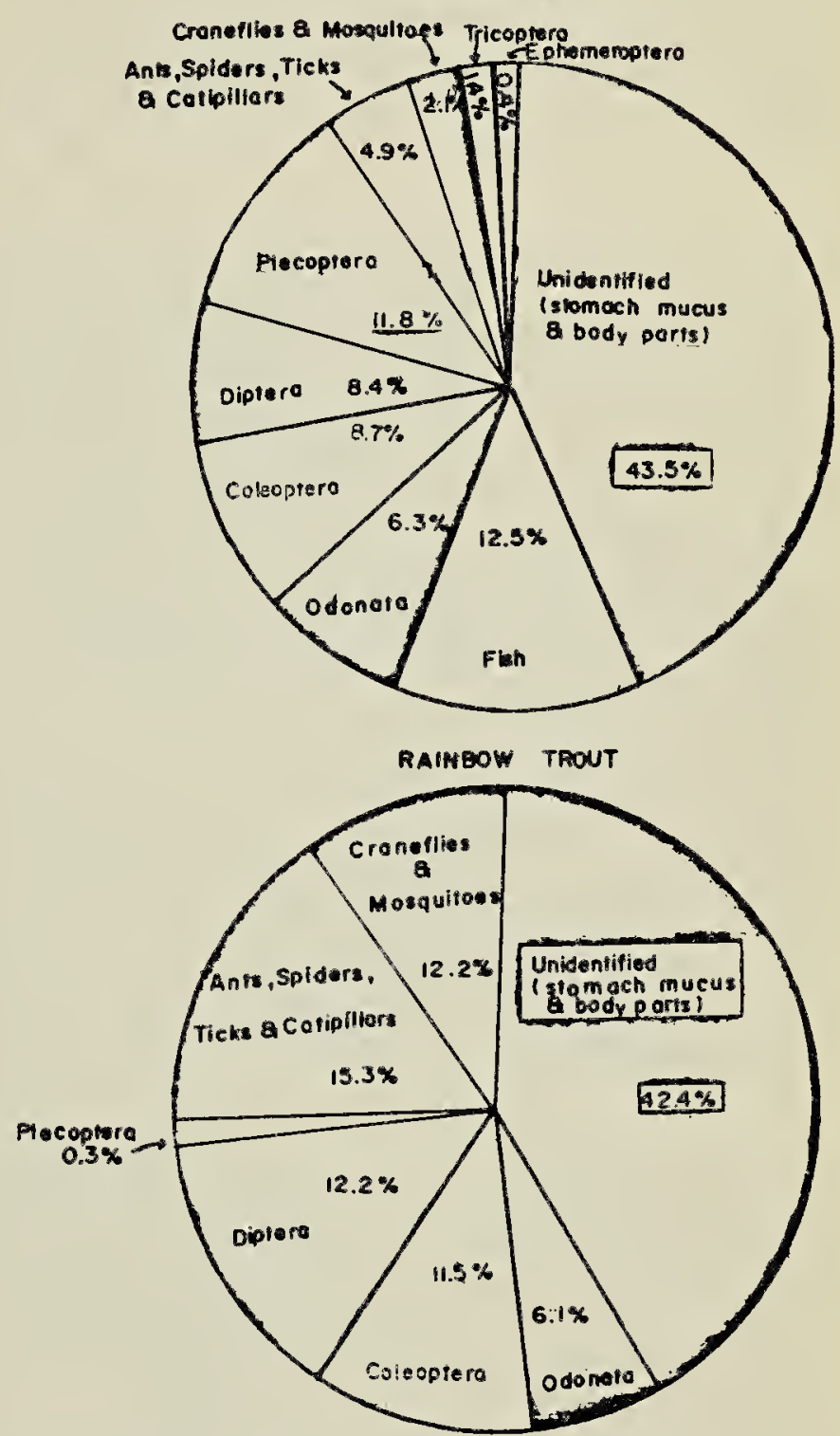

Figure 1: Stomach content analysis.

material shows that specialized equipment and techniques would have to be used to identify these objects to get a true picture of the fish's diet.

Figure 1 shows that brook trout are more selective in what they eat com- 
TABLE 1 - Stomach Contents of Brook Trout and Rainbow Trout

\begin{tabular}{|l|c|c|c|c|}
\hline Brook Trout & $\begin{array}{c}\text { No. of fish } \\
\text { sampled }\end{array}$ & $\begin{array}{c}\text { Aver. stomach } \\
\text { contents/fish }\end{array}$ & $\begin{array}{c}\text { Range of } \\
\text { stomach contents }\end{array}$ & $\begin{array}{c}\text { Total contents } \\
\text { analyzed }\end{array}$ \\
\hline Baseline Creek & 16 & $0.64 \mathrm{ml}$ & $0.1-1.5 \mathrm{ml}$ & $10.3 \mathrm{ml}$ \\
Hardisty Creek & 3 & $1.36 \mathrm{ml}$ & $1.0-2.0 \mathrm{ml}$ & $4.1 \mathrm{ml}$ \\
\hline Rainbow Trout & & & & \\
\hline \hline Baseline Creek & 3 & $1.03 \mathrm{ml}$ & $0.7-1.4 \mathrm{ml}$ & $3.1 \mathrm{ml}$ \\
Hardisty Creek & 16 & $0.63 \mathrm{ml}$ & $0.2-2.0 \mathrm{ml}$ & $10.0 \mathrm{ml}$ \\
\hline
\end{tabular}

pared to rainbow trout. Therefore, I feel that both could be stocked in the same lake or stream, providing there are a wide variety of organisms for food.

\section{ADDITIONAL RECORDS OF THE RED-SIDED GARTER SNAKE IN SASKATCHEWAN}

D. M. SECOY, Department of Biology, University of Regina, and P. RAMAEKERS, Saskatchewan Department of Mineral Resources, Regina, Saskatchewan.

The Red-sided Garter Snake (Thamnophis sirtalis parietalis) has been reported in Saskatchewan at Estevan and Amisk Lake. ${ }^{2}{ }^{1}$ It has also been seen in the Cypress Hills (personal communication, members of the Regina Natural History Society). We hereby report sightings of this species south of Lake Athabasca at $110^{\circ} 00^{\prime} \mathrm{W}, 58^{\circ} 07^{\prime} \mathrm{N}$ on
'LANGLER, K. 1972. Freshwaster fishery biology. C. Brown Co. Publishers, Dubuque, lowa.

2NEEDHAM, J. 1976. A guide to the study of fresh-water biology. Holden-Day, Inc., San Francisco.
June, 1978 on a boulder esker near a marsh, and another $3 \mathrm{~km}$ south of Cluff Lake on 19 August, 1979, on a south-facing rocky slope. Both were sightings of single animals.

This species has been reported along the Birch River draining into Lake Athabasca in Alberta, and at Fort Smith, Northwest Territories. ${ }^{1}$ Therefore, its presence in the boreal forest south of Lake Athabasca in the Athabasca basin is not unexpected.

'LOGIER, E. B. S. and G. C. TONER. 1961. Check List of the Amphibians and Reptiles of Canada and Alaska. Contrib. No. 53, Life Sciences Div., Royal Ontario Museum.

${ }^{2}$ NERO, R. W. 1957. Observations on a garter snake hibernaculum. Blue Jay 15:116-118. 